\title{
Limitations when use chloramphenicol-b- cyclodextrins complexes in ophtalmic solutions buffered with boric acid/borax system
}

\author{
Todoran Nicoleta, Ciurba Adriana*, Rédai Emőke, Ion V, Lazăr Luminița, Sipos Emese \\ University of Medicine and Pharmacy of Tirgu Mures
}

Chloramphenicol eye drops are commonly prescribed in concentrations of $0.5-1 \%$ in the treatment of infectious conjunctivitis. In terms of ophthalmic solution preparation, the major disadvantage of chloramphenicol consists in its low solubility in water. The solubility is increased by substances that form chloramphenicol-complexes, for example: boric acid/borax or cyclodextrins. Objective: Experimental studies aimed to evaluate the potential advantages of enhancing the solubility and stability of chloramphenicol (API) by molecular encapsulation in b-cyclodextrin (CD), in formulation of ophthalmic solutions buffered with boric acid/borax system. Methods and Results: We prepared four APIb-CD complexes, using two methods (kneading and co-precipitation) and two molar ratio of APl/b-cyclodextrin (1:1 and 1:2). The formation of complexes was proved by differential scanning calorimetry (DSC) and the in vitro dissolution tests. Using these compounds, we prepared eight ophthalmic solutions, formulated in two variants of chloramphenicol concentrations $(0.4 \%$ and $0.5 \%)$. Each solution was analyzed, by the official methods, at preparation and periodically during three months of storing in different temperature conditions $\left(4^{\circ} \mathrm{C}, 20^{\circ} \mathrm{C}\right.$ and $\left.30^{\circ} \mathrm{C}\right)$. Conclusions: Inclusion of chloramphenicol in b-cyclodextrin only partially solves the difficulties due to the low solubility of chloramphenicol. The protection of chloramphenicol molecules is not completely ensured when the ophthalmic solutions are buffered with the boric acid/borax system.

Keywords: chloramphenicol, b-cyclodextrin complexes, ophthalmic solutions, boric acid/borax system

Received: 9 December 2014 / Accepted: 20 December 2014

\section{Introduction}

Chloramphenicol eye drops are commonly prescribed in concentrations of $0.5-1 \%$ in the treatment of infectious conjunctivitis, this antibiotic taking the advantage of a broad-spectrum coverage of most gram-positive, gram negative and anaerobic bateria $[1,2]$.

In terms of ophthalmic solution preparation, the major disadvantage of chloramphenicol as active pharmaceutical ingredient (API) consists in its low solubility in water (1:400) which allows the obtaining of solutions only up to $0.25 \%(\mathrm{pH}=4.5$ to 7.5$)$. In such solutions, chloramphenicol is stable in the $\mathrm{pH} 2$ to 9 range. The solubility of chloramphenicol is increased by substances that form slightly soluble chloramphenicol-complexes, for example: boric acid/sodium tetraborate (borax) or cyclodextrin (CD). Such complexes make possible the achieving of solutions more concentrated in chloramphenicol $(0.5-8 \%)[3,4]$.

Classically, the eye drops containing $0.5-1 \%$ chloramphenicol are prepared using the method of dissolution by mild heating the API in buffer solutions containing boric acid/borax, thus forming chloramphenicol-boric acid/borax complex, in form of sodium salt. Solubility and stability of the resulted complex depend on the $\mathrm{pH}$ created in solution by the buffer system. As a consequence: $0.5 \%$ chloramphenicol in solution is obtained at $\mathrm{pH}=6.8$ to 7.2 (solution being stable 10-12 days, stored at room tem-

* Correspondence to: Adriana Ciurba

E-mail: adriana.ciurba@umftgm.ro perature) and $1 \%$ chloramphenicol in solution is obtained at $\mathrm{pH} 8.6$ (solution being stable 2-5 days, stored at cool temperature). Boric acid limits the hydrolysis of chloramphenicol in neutral solutions, but at $\mathrm{pH}>9$ the hydrolytic cleavage of $\mathrm{C}-\mathrm{Cl}$ bonds (and probably at the amide group, too) occurs rapidly, forming inactive therapeutic products $[5,6]$.

Lately, the obtaining of chloramphenicol-cyclodextrins complexes (API-CD) was intended for two purposes: to increase the solubility of API in water and to increase the stability of solution by avoiding the degradation reactions, due to the molecular encapsulation of API in cyclodextrins. $\beta$-cyclodextrin $(\beta-C D)$ and its derivatives (dimethyl$\beta$-cyclodextrin, hydroxypropyl- $\beta$-cyclodextrin etc.) have been used in these cases, whereas the aromatic structure and size of the chloramphenicol molecule are appropriate for this type of cyclodextrins $[7,8,9,10]$.

In our previous work, we prepared chloramphenicol$\beta$-cyclodextrin complexes (API- $\beta$-CD), using two technological methods: kneading and co-precipitation, respectively. In both cases, using different analytical methods, we demonstrated the complexes formation in two molar ratios: API- $\beta$-CD 1:1 and 1:2, respectively. We also demonstrated, by a microbiological method, the maintaining of therapeutic effectiveness for the $0.5 \%$ chloramphenicol eye solutions prepared by dissolving the API- $\beta-C D$ complexes in water [11].

The experimental studies presented in this paper aimed to evaluate the potential advantages of enhancing the solu- 
bility and stability of chloramphenicol by molecular encapsulation in $\beta$-cyclodextrin, in formulation of ophthalmic solutions buffered with boric acid/borax system.

\section{Material and methods}

Chemicals: Chloramphenicol (Sigma Aldrich, Germany); $\beta$-cyclodextrin (Cyclolab, Hungary); boric acid, sodium tetraborate, phenylmercuric borate, lactose, plysorbate 80, distillated water (pharmaceutical grade); ethanol (p.a.); the used reference industrial product (IND) was: "Sificetina" (1300130LOTTO902), in form of powder and solvent for eye drops (produced by S.I.F.I. SPA, Italia), a product bought from a community pharmacy.

\section{Preparation of solid compounds:}

- Kneading method $\left(M_{1: 1}, M_{1: 2}\right)$ : physical mixtures of chloramphenicol $(1.00 \mathrm{~g}, 0.0031 \mathrm{~mol})$ and $\beta$-cyclodextrin in molar ratio of $1: 1(3.51 \mathrm{~g}, 0.0031 \mathrm{~mol})$ and $1: 2(7.02 \mathrm{~g}$, $0.0062 \mathrm{~mol}$ ), respectively, were moistened with mixtures of water-ethanol in ratio of 5:2 (4.51 g) and 5:1 (8.02 g), respectively, and then manually kneaded for $30 \mathrm{~min}$, in a granite mortar. The resulted pastes had been dried at 40 ${ }^{\circ} \mathrm{C}$ for $24 \mathrm{~h}$ and then sieved, resulting in powders with particle size of 250-315 $\mu \mathrm{m}$.

- Co-precipitation method $\left(C_{1: 1}, C_{1: 2}\right): 3.51 \mathrm{~g}(7.02 \mathrm{~g}$, respectively) of $\beta$-cyclodextrin was dissolved in $50.0 \mathrm{~g}$ (100.0 g, respectively) of water; each solution was then mixed with $1.00 \mathrm{~g}$ of chloramphenicol prior dissolved in $20.0 \mathrm{~g}$ of ethanol. The resulting suspensions were stirred at $50{ }^{\circ} \mathrm{C}$ for $30 \mathrm{~min}$, in a magnetic stirrer, and then evaporated at $50^{\circ} \mathrm{C}$, in a vacuum rotary evaporator. The precipitates had been dried at $40{ }^{\circ} \mathrm{C}$ for $24 \mathrm{~h}$ and then sieved, resulting in powders with particle size of 250-315 $\mu \mathrm{m}$.

- Physical mixture: was prepared by homogenous blending of previously sieved and weighted of chloramphenicol $(1.00 \mathrm{~g}, 0.0031 \mathrm{~mol})$ and $\beta$-cyclodextrin in molar ratio of $1: 1(3.51 \mathrm{~g}, 0.0031 \mathrm{~mol})$ in a mortar.

\section{Methods for analyze the solid compounds:}

- Determination of solubility in water: The sample of 0.010 $\mathrm{g}$ was placed into a test tube and portions of $0.1 \mathrm{ml}$ distilled water have been successively added, recording the volume of water in which the sample was dissolved, resulting in a clear solution.

- Determination of acidity/alkalinity $(p H)$ : The sample $(\sim 0.50 \mathrm{~g}$ chloramphenicol) was dissolved in $100 \mathrm{ml}$ distilled water and the $\mathrm{pH}$ of solution has been determined at $25^{\circ} \mathrm{C}$ (Consort-C 831- Multiparameter analyzer).

- Determination of the chloramphenicol content (assay): The sample ( $\sim .100 \mathrm{~g}$ chloramphenicol) was dissolved in water and then diluted, according with the official method. The diluted solution was analyzed by officinal method, at $278 \mathrm{~nm}, \mathrm{~A}_{278 \mathrm{~nm}}(1 \%, 1 \mathrm{~cm})=298$ (Jasco-V-530 spectrophotometer) [12].
- Differential scanning calorimetry - DSC [13]: The sample was placed into pierced an aluminum container and subjected to a temperature range of $10-300^{\circ} \mathrm{C}$ at a heating rate of $5^{\circ} \mathrm{C} / \mathrm{min}$ (Mettler Toledo STAR system).

- In vitro dissolution test. was performed by USP-rotating basket method (dissolution apparatus, Erweka model). Experimental conditions: sample quantity depending of the product type (API- $100 \mathrm{mg} ; \mathrm{M}_{1: 1}$ and $\mathrm{C}_{1: 1^{-}} 450 \mathrm{mg}$, respectively; $\mathrm{M}_{1: 2}$ and $\mathrm{C}_{1: 2^{-}} 800 \mathrm{mg}$, respectively); 900 $\mathrm{ml}$ water at $37^{\circ} \mathrm{C} \pm 1^{\circ} \mathrm{C}, 100 \mathrm{rpm}$; solution samples $(5$ $\mathrm{ml}$ ), filtered through nylon disc filter (pore of $0.45 \mu \mathrm{m}$ ) and analiyed, after dilution, by spectrophotometer, at $278 \mathrm{~nm}$; quantity of released chloramphenicol was determined by calibration curve method (series of solutions prepared by dissolving $8,10,12,14,15 \mathrm{mg}$ chloramphenicol in water/methanol 1:1) and expressed as percentage of the initial content. Software for statistical analyzes of dissolution curves: DDSolver as Add-In Microsoft Excel Program [14].

\section{Preparation and storage of ophthalmic solutions:}

- Laboratory products preparation: The solutions were prepared aseptically, respecting the general rules of preparation: boric acid and borax were dissolved in boiling water, chloramphenicol at $50{ }^{\circ} \mathrm{C}$ and after cooling the other components (including the chloramphenicol $\beta$-cyclodextrin complexes) were dissolved, or added in form of solution (phenylmercuric borate). Each solution was finally completed with water and then packaged in sailed brown glass containers.

- Industrial product preparation: The solid part was dissolved in the provided solvent.

- Storage of ophthalmic solutions for testing their stability: After preparation, each ophthalmic solution was divided in 3 portions, sealed in brown glass containers, and then stored for 3 months, protected from light, in different temperature conditions: $4^{\circ} \mathrm{C} \pm 2^{\circ} \mathrm{C}$ (refrigerator), $20^{\circ} \mathrm{C}$ $\pm 5^{\circ} \mathrm{C}$ (in a pharmacy store), $30^{\circ} \mathrm{C} \pm 0.2{ }^{\circ} \mathrm{C}$ (oven). Samples were collected periodically, at intervals of one month.

\section{Methods for ophthalmic solutions analysis:}

- Aspect: $10.0 \mathrm{ml}$ solution (the sample) was placed in a test tube and compared with $10 \mathrm{ml}$ of water, visualizing the fluid layers on a black background.

- Determination of acidity/alkalinity ( $p H): 30 \mathrm{ml}$ solution (the sample) was analyzed by the same method described above.

- Determination of the chloramphenicol content (assay): The sample ( 0.025 g chloramphenicol) was diluted with water and the proper dilution was spectrophotometrically analyzed as it was described above.

- Comparative analysis: GraphPad Software, statistical methods $[15,16]$. 


\section{Results and discussions}

\section{Characteristics of solid products:}

One of the objectives of our study was to prepare solid compounds that can be easily used for the preparation of ophthalmic solutions in concentrations of 0.4 or $0.5 \%$ chloramphenicol. As a result, we prepared a number of four chloramphenicol- $\beta$-cyclodextrin complexes (noted $\left.1-\mathrm{M}_{1: 1}, 2-\mathrm{M}_{1: 2}, 3-\mathrm{C}_{\mathrm{cp} 1: 1}, 4-\mathrm{C}_{\mathrm{cp} 1: 2}\right)$, which were characterized by determination of: chloramphenicol content, solubility in water and $\mathrm{pH}$ of the resulting solution (Figure 1). As comparison references, three compounds were used: chloramphenicol (5-API), the powder of an industrial product $\left(6-\mathrm{IND}_{\mathrm{p}}\right)$ and the $\beta$-cyclodextrin $(\beta-\mathrm{CD})$ used for the preparation of the solid compounds (API- $\beta-C D$ complexes).

The results of the performed analyzes show that the obtained solid products contain chloramphenicol in different proportions, depending on the preparation method applied, but they show a better solubility than chloramphenicol and also a slightly acidity which remains in range of $\mathrm{pH}$ 6-7.

\section{Formation of inclusion complexes and their release ca-} pacity:

- Differential scanning calorimetry- DSC (Figures 2-3):

The thermo-analytical curves of control compounds (Figure 2) show that: chloramphenicol (5-API) melts at 25 $\mathrm{min} /$ which corresponds to a temperature of $150^{\circ} \mathrm{C}$; and $\beta$-cyclodextrin $(\beta-\mathrm{CD})$ melts at about $47 \mathrm{~min} / 240-245^{\circ} \mathrm{C}$. In case of their $1: 1$ physical mixture, the curve shows distinctly: the moment when $\beta$-CD loses its crystallization water- at about $60^{\circ} \mathrm{C}(7-8 \mathrm{~min})$, the moment when chloramphenicol melts- at $150^{\circ} \mathrm{C}(25 \mathrm{~min})$ and the moment when $\beta$-CD caramelizes- at $245^{\circ} \mathrm{C}(44-45 \mathrm{~min})$.

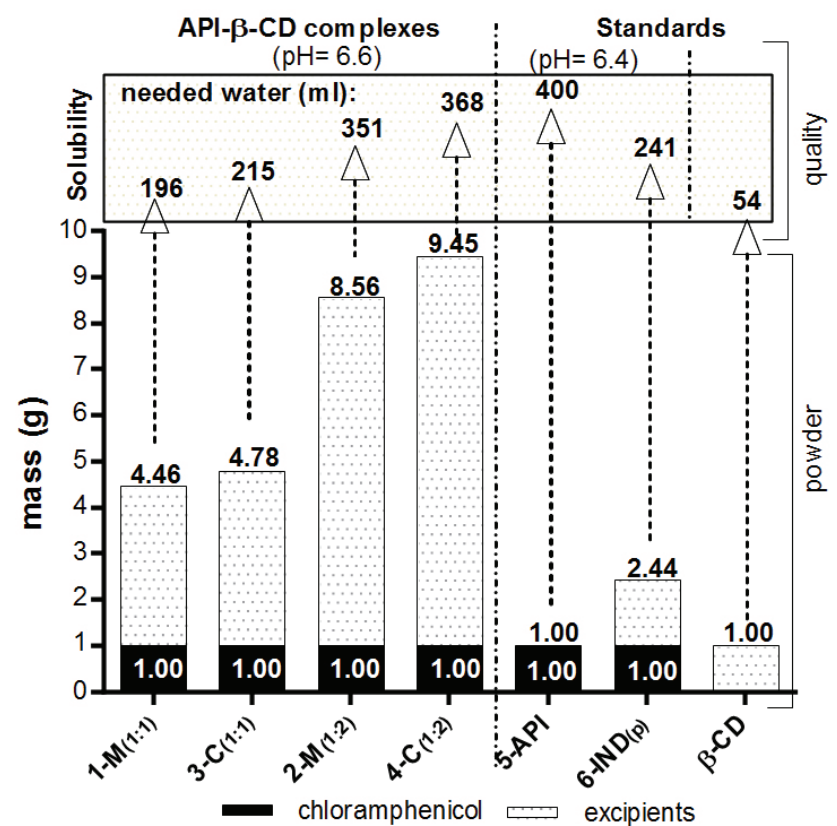

Fig. 1. The content, the solubility and the $\mathrm{pH}$ of the analyzed solid compounds
The thermo-analytical curves of the fourth chloramphenicol- $\beta$-cyclodextrin complexes tested (Figure 3) show in all cases the moments of the $\beta$-CD dehydration (at about 6-9 $\mathrm{min}$ ) and then that of caramelization (at about $50 / 51 \mathrm{~min}$ ), while the moment of chloramphenicol melting no longer appears. These behaviors demonstrate the formation of API- $\beta$-CD inclusion complexes in all four products obtained in laboratory.

\section{- In vitro release of chloramphenicol from $\beta$-cyclodextrin com- plexes (Figure 4):}

The comparative analysis of dissolution profiles show that chloramphenicol dissolves faster from the $\beta$-cyclodextrin complexes obtained by kneading method (1- $\mathrm{M}_{1: 1}$ and $\left.2-\mathrm{M}_{1: 2}\right)$ than those obtained by co-precipitation method $\left(3-\mathrm{C}_{1: 1}, 4-\mathrm{C}_{1: 2}\right)$. These observations suggest that co-precipitation determines the formation of more stable complexes. Also, the higher the amount of $\beta$-cyclodextrin $\left(2-\mathrm{M}_{1: 2}\right.$ and $\left.4-\mathrm{C}_{1: 2}\right)$, the faster the chloramphenicol is released. In the case of 3-C $\mathrm{C}_{1: 1}$ compound, the chloramphenicol rate release from complex is even similar with that of the chloramphenicol dissolution.

\section{Characteristics of ophthalmic solutions:}

- Composition and characteristics determined after preparation:

Products in form of ophthalmic solutions were prepared in two variants of chloramphenicol concentration: $0.5 \%$ (A-series) and $0.4 \%$ (B-series). As references products, we prepared three ophthalmic solutions: with chloramphenicol (API-A, API-B) and the industrial product (IND-B).

The used excipients were added as: stabilizing agents in form of $\mathrm{pH}$ buffer system (boric acid/sodium tetraborate), osmotic agent (lactose), surfactant (polisobate 80) and antimicrobial preservative (phenylmercuric borate).

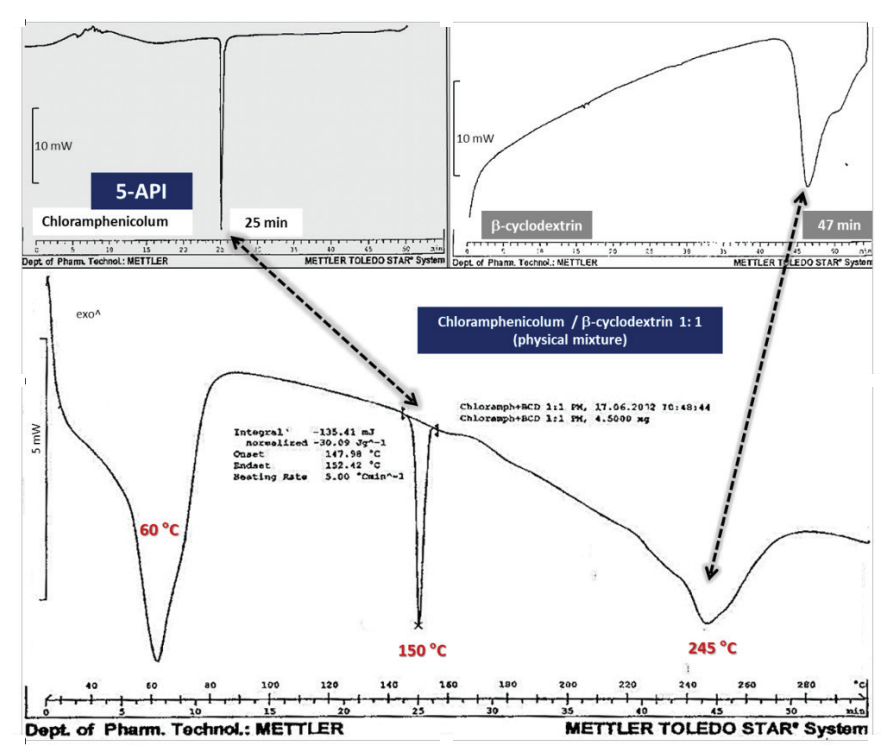

Fig. 2. The thermo-analytical curves (DSC) of compounds used as control 


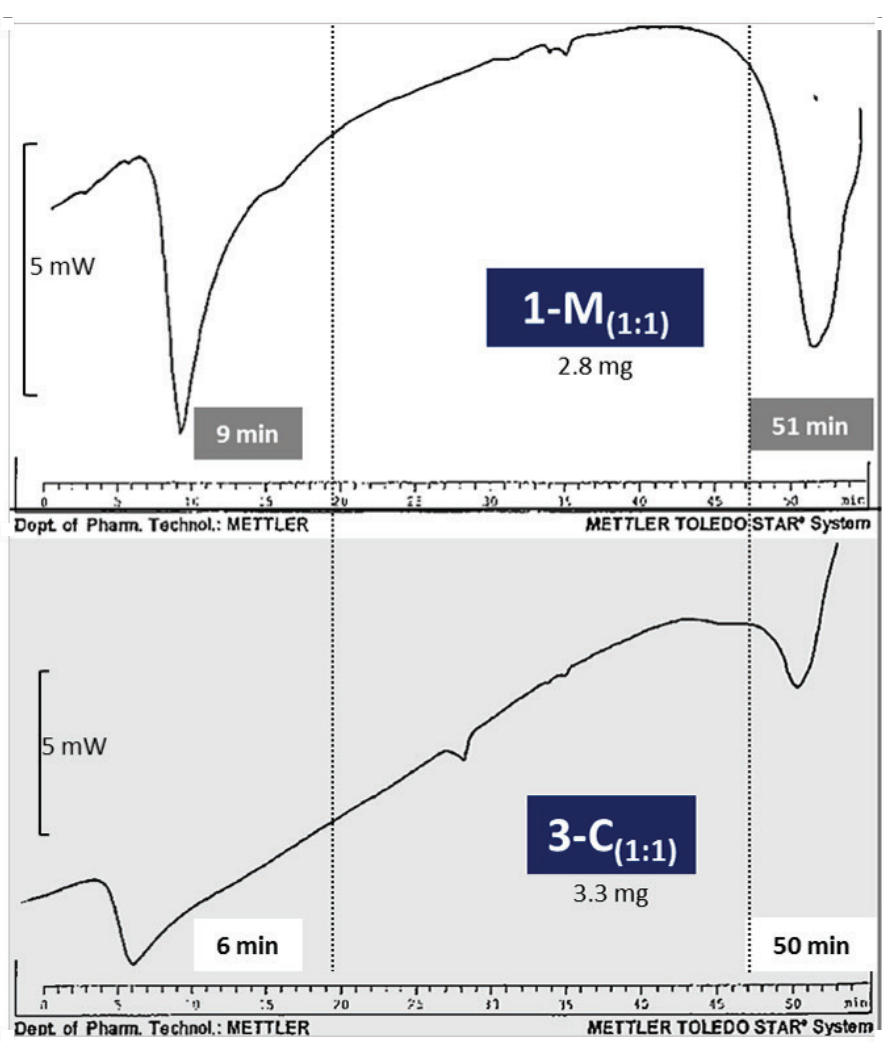

Fig. 3. The thermo-analytical curves (DSC) of tested compounds

The resulted ophthalmic solutions were coded according to Table I.

The obtained ophthalmic solutions were characterized immediately after preparation. In all cases $\mathrm{pH}$ solutions ranged into 7 to 7.5 interval, according to requirements. The appearance of solutions is not clear in every case, due to the differences in solubility. Even if the solubility of chloramphenicol included in $\beta$-cyclodextrin is increased, the solubility of complexes (especially of those with higher amounts of $\beta-C D, 1: 54$ water soluble) still remains a lim-

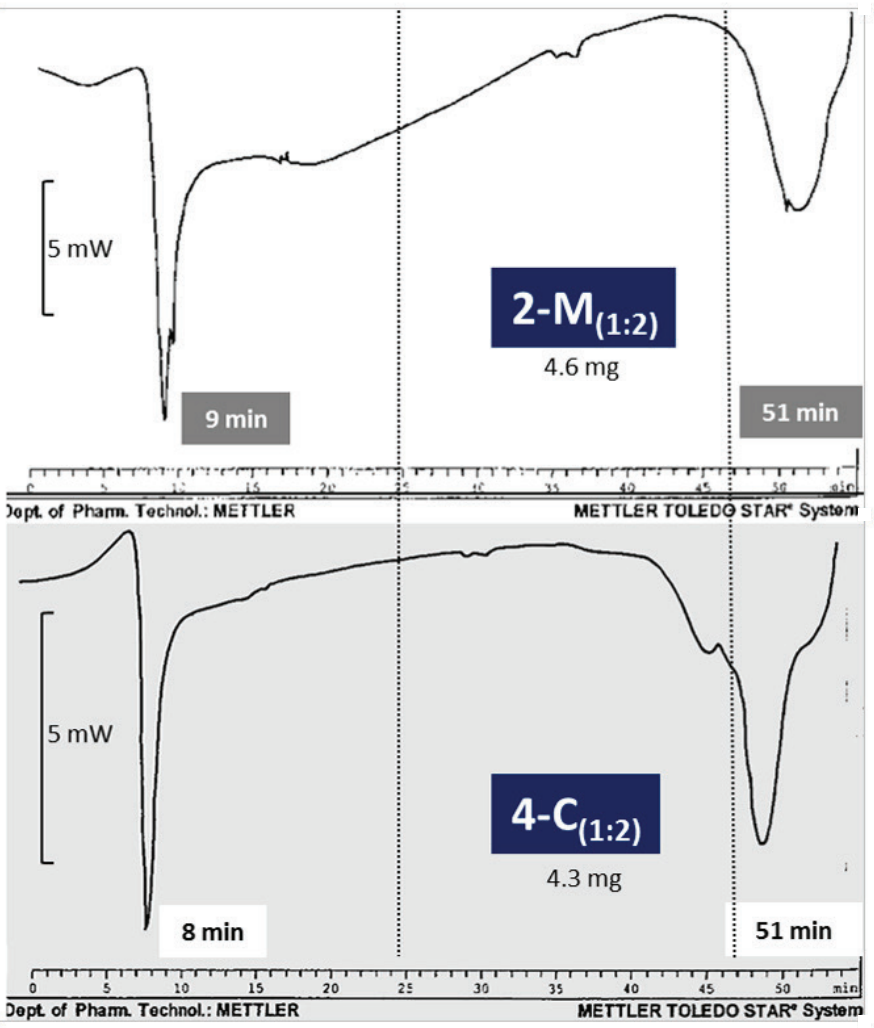

iting factor if concentrations of $0.4-0.5$ chloramphenicol are intended.

In all cases, the chloramphenicol concentrations determined after solutions preparation were situated in the required limits of $\pm 10 \%$ of the declared content, namelly: $0,45-0,55 \%$ (series A) and 0,36-0,44\% (series B).

\section{- Influence of storing conditions on the stability:}

Each formulation was then stored for three months in different temperature conditions $\left(4^{\circ} \mathrm{C}, 20^{\circ} \mathrm{C}\right.$ and $30^{\circ} \mathrm{C}$,

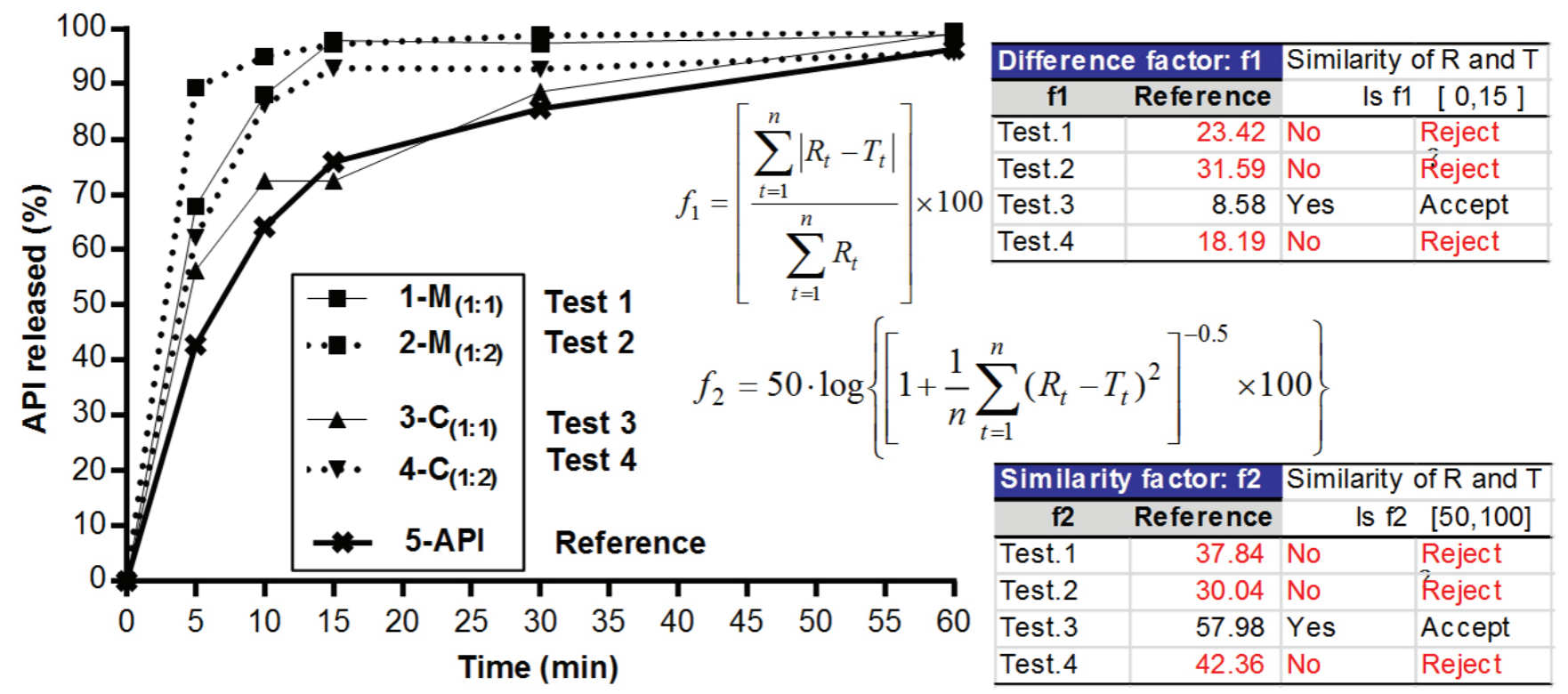

Fig. 4. Release of chloramphenicol (API) from the tested inclusion complexes (test 1-4) and the results of the statistical comparison with dissolution profile of chloramphenicol (reference) 
Table I. Chloramphenicol (API) eye drops formulations

\begin{tabular}{|c|c|c|c|c|c|c|}
\hline \multicolumn{4}{|c|}{ Composition } & \multicolumn{3}{|c|}{ Quality } \\
\hline $\begin{array}{l}\text { API conc. } \\
\text { (batch) }\end{array}$ & \multicolumn{2}{|c|}{$\begin{array}{l}\% \text { active ingredient/ } \\
\text { code }\end{array}$} & $\begin{array}{l}\text { excipients } \\
(\%)\end{array}$ & Code & $\begin{array}{l}\text { Aspect of liquid } \\
\text { dispersion* }\end{array}$ & $\mathrm{pH}$ \\
\hline \multirow{5}{*}{$\begin{array}{l}0,5 \mathrm{mg} / \mathrm{ml} \\
\text { (A) }\end{array}$} & \multirow{2}{*}{2.25} & $1-\mathrm{M}_{(1: 1)}$ & \multirow{5}{*}{$\begin{array}{c}\text { boric acid (1.6) } \\
\text { sodium tetraborate }(0.5) \\
\text { phenylmercuric borate solution } 0.2 \%(0.5) \\
\text { purified water (add. to100.0) }\end{array}$} & $1-\mathrm{A}$ & - & 7.2 \\
\hline & & $3-C_{(1: 1)}$ & & $3-A$ & ++ & 7.2 \\
\hline & \multirow{2}{*}{4.01} & $2-\mathrm{M}_{(1: 2)}$ & & $2-A$ & + & 7.2 \\
\hline & & $4-C_{(1: 2)}$ & & $4-A$ & ++ & 7.2 \\
\hline & 0.50 & 5-API & & $5-\mathrm{A}$ & - & 7.2 \\
\hline \multirow{6}{*}{$\begin{array}{c}0,4 \\
\mathrm{mg} / \mathrm{ml} \\
\text { (B) }\end{array}$} & \multirow{2}{*}{1.80} & $1-\mathrm{M}_{(1: 1)}$ & \multirow{5}{*}{$\begin{array}{c}\text { boric acid }(1.5) \\
\text { sodium tetraborate }(0.3) \\
\text { lactose }(1.6) \\
\text { polysorbate } 80(0.3) \\
\text { phenylmercuric borate solution } 0.2 \%(0.4) \\
\text { purified water (add. to100.0) }\end{array}$} & 1-B & - & 7.3 \\
\hline & & $3-C(1: 1)$ & & $3-B$ & +++ & 7.3 \\
\hline & \multirow{2}{*}{3.20} & $2-M(1: 2)$ & & $2-B$ & ++ & 7.3 \\
\hline & & $4-C(1: 2)$ & & $4-B$ & +++ & 7.3 \\
\hline & 0.40 & 5-API & & $5-B$ & - & 7.2 \\
\hline & 2.00 & 6-IND(p) & provided solvent (add. to100) & $6-B$ & - & 7.0 \\
\hline
\end{tabular}

*Scale of appearance (visual inspection):

clear (-); very slightly opalescent (+), slightly opalescent (++), opalescent (+++)
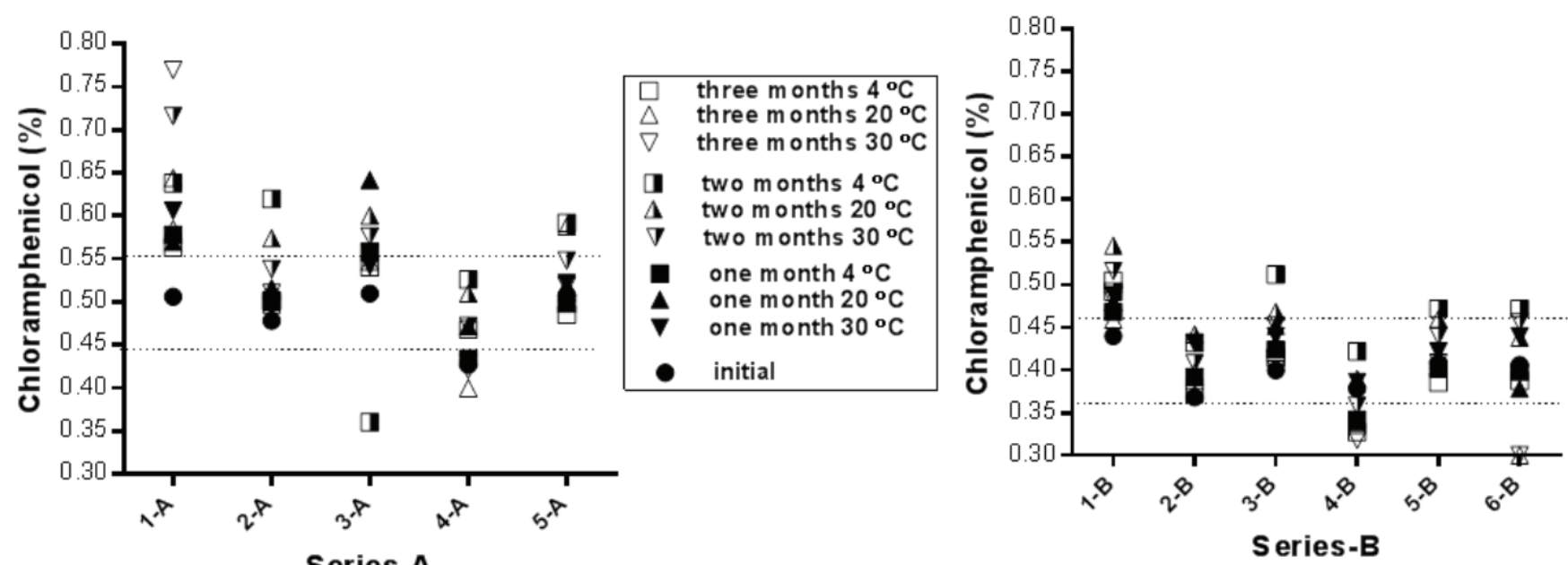

Fig. 5. Content of chloramphenicol determined in ophthalmic formulations stored in different temperatures conditions and the accepted intervals: series-A $(0.5 \%$ declared content) and series-B $(0.4 \%$ declared content)

Table II. The statistical significance of implied variables influences on the amount of chloramphenicol in the ophthalmic solutions

\begin{tabular}{|c|c|c|c|c|c|}
\hline $\begin{array}{l}\text { Two way ANOVA } \\
\text { Alpha }\end{array}$ & $\begin{array}{l}\text { Ordinary } \\
0.05\end{array}$ & & & & Series-A \\
\hline Source of variation & $\%$ of total variation & $P$ value & $\mathrm{P}$ value summary & Significant? & \\
\hline Formulation composition & 47.48 & $<0.0001$ & 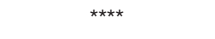 & Yes & \\
\hline Storage period/temperature & 15.33 & 0.1386 & ns & No & \\
\hline ANOVA table & SS & DF & MS & F(DFn, DFd) & $P$ value \\
\hline Formulation composition & 0.1330 & 4 & 0.03326 & $F(4,36)=11.49$ & $P<0.0001$ \\
\hline $\begin{array}{l}\text { Storage } \\
\text { period/temperature }\end{array}$ & 0.04249 & 9 & 0.004771 & $F(9,36)=1.648$ & $P=0.1386$ \\
\hline Residual & 0.1042 & 36 & 0.002895 & & \\
\hline $\begin{array}{l}\text { Two way ANOVA } \\
\text { Alpha }\end{array}$ & $\begin{array}{l}\text { Ordinary } \\
0.05\end{array}$ & & & & Series-B \\
\hline Source of variation & $\%$ of total variation & $P$ value & $P$ value summary & Significant? & \\
\hline Formulation composition & 32.61 & & & Yes & \\
\hline Storage period/temperature & 23.83 & & & No & \\
\hline ANOVA table & SS & DF & MS & $\mathrm{F}(\mathrm{DFn}, \mathrm{DFd})$ & $P$ value \\
\hline Formulation composition & 0.01390 & 5 & 0.02779 & $F(5,45)=6.739$ & $P<0.0001$ \\
\hline Storage period/temperature & 0.1016 & 9 & 0.01128 & $F(9,45)=2.736$ & $P=0.0123$ \\
\hline Residual & 0.1856 & 45 & 0.004124 & & \\
\hline
\end{tabular}


respectively) and their quality determined periodically after every month. During the three months of storage, $\mathrm{pH}$ of solutions was maintained without significant variations, excepting some $0.5 \%$ solutions prepared with cyclodextrins complexes in which $\mathrm{pH}$ reached to 7.6 , but not correlated to temperature.

The variation of active ingredient amounts during the storage of solution in different conditions of temperature and the statistical significance of implied variables influences are summarized in Figure 5 and Table II.

The results presented in Figure 5 show that the amount of chloramphenicol is variable in solutions during the three months of storage, regardless of temperature. Even so, the solutions prepared with compound 2- $\mathrm{M}_{1: 2}(2-\mathrm{A}$ and 2-B) appears to be more stable, especially at lower concentration of chloramphenicol $(0.4 \%$ - in $2-B)$. This observation is more valuable, considering that, according to the results presented in Figure 6, the storage conditions significantly affect the amount of chloramphenicol in case of series- $\mathrm{B}$ of ophthalmic solutions.

\section{Conclusions}

Inclusion of chloramphenicol in b-cyclodextrin only partially solves the difficulties due to the low solubility of chloramphenicol when the preparation of $0.4-0.5 \%$ chloramphenicol ophthalmic solutions is intended. The chloramphenicol-b-cyclodextrin prepared by kneading method in molar ratio of $1: 2$ could be useful, especially for up to $0.4 \%$ chloramphenicol solutions. The protection of chloramphenicol by molecular encapsulation in b-cyclodextrin is not completely ensured when the ophthalmic solution is buffered with the boric acid/borax system.

\section{References}

1. Sweetman SC et al- Martindale: The Complete Drug Reference, 36th edition, Pharmaceutical Press, London, UK, 2009;239-242.

2. Falagas ME, Grammatikos AP, Michalopoulos A-Potential of oldgeneration antibiotics to address current need for new antibiotics, Expert Rev Anti Infect Ther, 2008;6(5):593-600.

3. Oniga O, Tiperciuc B- Antibiotice antibacteriene, Ed. Medicală, ClujNapoca, 2003;203-212.

4. Vlaia L, Lupuleasa D, Coneac G, et al- Prepararea medicamentelor- baze practice, vol.I, Ed. Mirton, Timișoara, 2009;331-340.

5. James $\mathrm{KC}$, Leach $\mathrm{RH}-\mathrm{A}$ borax-chloramphenicol complex in aqueous solution, Journal of Pharmacy and Pharmacology, 1970; 22(8):612-614.

6. Boer Y, Pijnenburg A- HPLC determination of chloramphenicol degradation in eye drops, Pharmaceutisch Weekblad, 1983;5(3):95-101.

7. Abdel Rahman AA, Khidr SH, Ahmed SM, et al- Evaluation of chloramphenicol-b-cyclodextrin inclusion complex, Eur. J. Pharm. Biopharm. 1991;37(1):34-37.

8. Ramos Al, Braga TM, Silva P, et al- Chloramphenicol-cyclodextrin inclusion compounds: co-dissolution and mechanochemical preparations and antibacterial action, CrystEngComm, 2013;15:2822-2834.

9. Zuorro A, Fidaleo M, Laveccia R-Solubility enhancement and antibacterial activity of chloramphenicol included in modified b-cyclodextrins, Bull. Korean Chem. Soc., 2010;31(11):3460-3462.

10. Loftsson $T$, Jarho P, Másson M, Järvinen T- Cyclodextrins in drug delivery: review, Expert Opin. Frug Deliv., 2005;2:335-351.

11. Sipos E, Kovács O, Lörinczi L- Formulation and microbiology analysis of multidose eye drops obtained with inclusion complex of chloramphenicol, Orvostudományi Értesitő, 2009;82(4):287-288.

12. British Pharmacopoeia, II-III, University Press, Cambridge, London, 2009;1239-41,8281-8282.

13. Menczel JD, Prime RB et al- Differential Scanning Calorimetry (DSC) in "Thermal Analysis of Polymers: Fundamentals and Applications", Wiley Inc, New Jersey, USA, 2009;7-240.

14. Young $Z$, Meirong $H$, Jianping $Z$ et al.- DDSolver: An Add-In Program for Modeling and Comparision of Drug Dissolution Profiles, The AAPS Journal, 2010;12(3):263-271.

15. Motulsky HJ, Christopoulos A- Fitting models to biological data using linear and nonlinear regression. A practical guide to curve fitting, GraphPad Software Inc, Sandiego CA, 2003 (www.graphpad.com);134-160.

16. Hibbert DB, Gooding JJ- Data Analysis for Chemistry: An Introductory Guid For Students and Laboratory Scientist, University Press, Oxford, 2006 (electronic edition);128-164. 